\title{
Incidental Discovery of Acinic Cell Carcinoma of the Oral Mucosa with Metachronous Adenoid Cystic Carcinoma of the Upper Lip
}

\author{
Hallazgo Incidental de Carcinoma de Células Acinares de la Mucosa \\ Oral con Carcinoma Adenoide Quístico Metacrónico del Labio Superior
}

Ana Luiza Dias Leite de Andrade'; Hugo Costa Neto'; Andréia Ferreira do Carmo'; Edilmar de Moura Santos; Adriano Rocha Germano² \& Hébel Cavalcanti Galvão³

\begin{abstract}
ANDRADE, A. L. D. L.; NETO, H. C.; DO CARMO, A. F.; SANTOS, E. M.; GERMANO, A. R. \& GALVÃO, H. C. Incidental discovery of acinic cell carcinoma of the oral mucosa with metachronous adenoid cystic carcinoma of the upper lip. Int. J. Odontostoma., 12(2):125-130, 2018.

ABSTRACT: Multiple salivary gland tumors represent an unusual event characterized by the development of composite lesions originated from minor or major salivary glands. These neoplasms can be categorized into three perspectives: Histologic type, time of appearance and topographic distribution. We report an unusual case of a 73-year-old black man with an acinic cell carcinoma (ACC) of the oral mucosa discovered incidentally during surgical removal of an adjacent mucocele. Approximately one year after the first consultation, the patient was seen at the local cancer reference center with a third lesion that was diagnosed as an adenoid cystic carcinoma (AdCC) of the upper lip. The patient underwent surgical reconstruction of the treated areas and has been free of the disease for the past year. To our knowledge, the combination of ACC and AdCC in intraoral sites has not been reported in the literature.
\end{abstract}

KEY WORDS: salivary gland neoplasms, acinic cell carcinoma, adenoid cystic carcinoma, second metachronous primary neoplasms.

\section{INTRODUCTION}

Generally, salivary gland neoplasms present as individual lesions and the occurrence of multiple tumors is unusual (Whitt et al., 2008). These neoplasms represent a heterogeneous group of lesions with diverse histological features and variable biologic behavior (Bell et al., 2005; Shishegar et al., 2011). Individual malignant salivary gland tumors are estimated to comprise approximately $3 \%$ of all head and neck cancers and usually show an unpredictable clinical course (Bell et al.). Among the various members that comprise this group of tumors, we highlight two neoplasms: acinic cell carcinoma (ACC) and adenoid cystic carcinoma (AdCC).

ACC is a malignant epithelial neoplasm arising from the salivary gland, in which at least some neoplastic cells exhibit serous acinar differentiation (Ellis \& Auclair, 2008). The tumor most commonly presents as a slow-growing, solitary, mobile or firm, and indolent or painful mass (Ellis \& Auclair; Triantafillidou et al., 2010). Histopathologically, ACC is considered an archetypical salivary gland tumor since it mimics normal serous salivary gland cells. Four architectural patterns are described: solid, papillarycystic, microcystic, and follicular. Although one pattern or cell type can predominate in an individual tumor, many exhibit a mixture of these features (Ellis \& Auclair; Omlie \& Koutlas, 2010).

AdCC is a rare malignant epithelial tumor of secretory glands with a biphasic differentiation into luminal (ductal) and abluminal (myoepithelial and basal)

\footnotetext{
${ }^{1}$ Oral Pathology Postgraduate Program, Department of Dentistry, Federal University of Rio Grande do Norte, Natal, RN, Brazil. ${ }^{2}$ Division of Oral and Maxillofacial Surgery, Department of Dentistry, Federal University of Rio Grande do Norte, Natal, RN, Brazil. ${ }^{3}$ Oral Pathology Postgraduate Program, Department of Dentistry, Federal University of Rio Grande do Norte, Natal, RN, Brazil.
} 
cells (Dubal et al., 2016; Luksic et al., 2016). Intraoral AdCC typically manifests as a hardened painless mass with slow and protracted growth (Dubal et al.). Microscopically, AdCC is characterized by a bidirectional differentiation of epithelial and myoepithelial cells, which usually demonstrates mixed growth patterns of cribriform, tubular and solid types. The classification of the histological subtype is commonly based on the predominant growth pattern in the specimen (Du et al., 2016).

Herein, we report an unusual case of ACC of the oral mucosa discovered incidentally during surgical removal of an adjacent mucocele with metachronous AdCC of the upper lip. Moreover, we discuss the clinical presentations, microscopic features and locations of intraoral malignant salivary gland neoplasms previously reported in the literature.

\section{CASE REPORT}

A 73-year-old black man was examined at the Service of Surgery and Maxillo-Orofacial Traumatology, Department of Dentistry, Federal University of Rio Grande do Norte (UFRN), with enlargement in the anterior region of the right oral mucosa. During anamnesis, the patient reported duration of 8 months and recurrent episodes of increasing and decreasing size of the lesion. $\mathrm{He}$ had a history of cheiloplasty during childhood and an iliac crest bone graft in the alveolar ridge 2 years ago. The patient smoked for 56 years and reported no use of medications or alcohol consumption. Clinical examination revealed the presence of an asymptomatic, mucosa-colored sessile mass measuring $1.5 \mathrm{~cm}$ in diameter (Fig. 1A). This clinical presentation led to the diagnostic hypothesis of a mucocele.

An excisional biopsy was performed and two distinct and anatomically separate lesions, but in close proximity to each other, were discovered during the surgical procedure (Fig. 1B-C). The surgical specimens were sent to the Pathological Anatomy Service of the Discipline of Oral Pathology, UFRN. Histopathological analysis of the smaller lesion revealed a pathological cavity delimited by an intense granulation reaction and partially filled with slightly eosinophilic amorphous material compatible with mucin containing abundant foamy macrophages (Fig. 2A-B). This first specimen was diagnosed as a mucus extravasation phenomenon.

The larger lesion was composed of a proliferation of neoplastic cells arranged in a predominant thyroidlike follicular pattern, which was characterized by the presence of multiple cystic spaces of variable size filled with an eosinophilic protein material (Fig. 2C). Delimiting these structures, cells exhibiting a polygonal morphology, an eccentric nucleus, prominent nucleoli, and no atypias or prominent mitoses were observed (Fig. 2D). Cells with clear cytoplasm could also be visualized. In focal areas of the specimen, the cellular elements were organized in a solid architectural pattern. The supporting stroma was sparse, and consisted of fibrovascular connective tissue permeated by a mild lymphoplasmacytic inflammatory infiltrate. Normal salivary gland parenchyma was also observed. Faced with such morphological findings, combined mammaglobin and S-100 immunohistochemistry was realized for diagnostic differentiation of ACC and
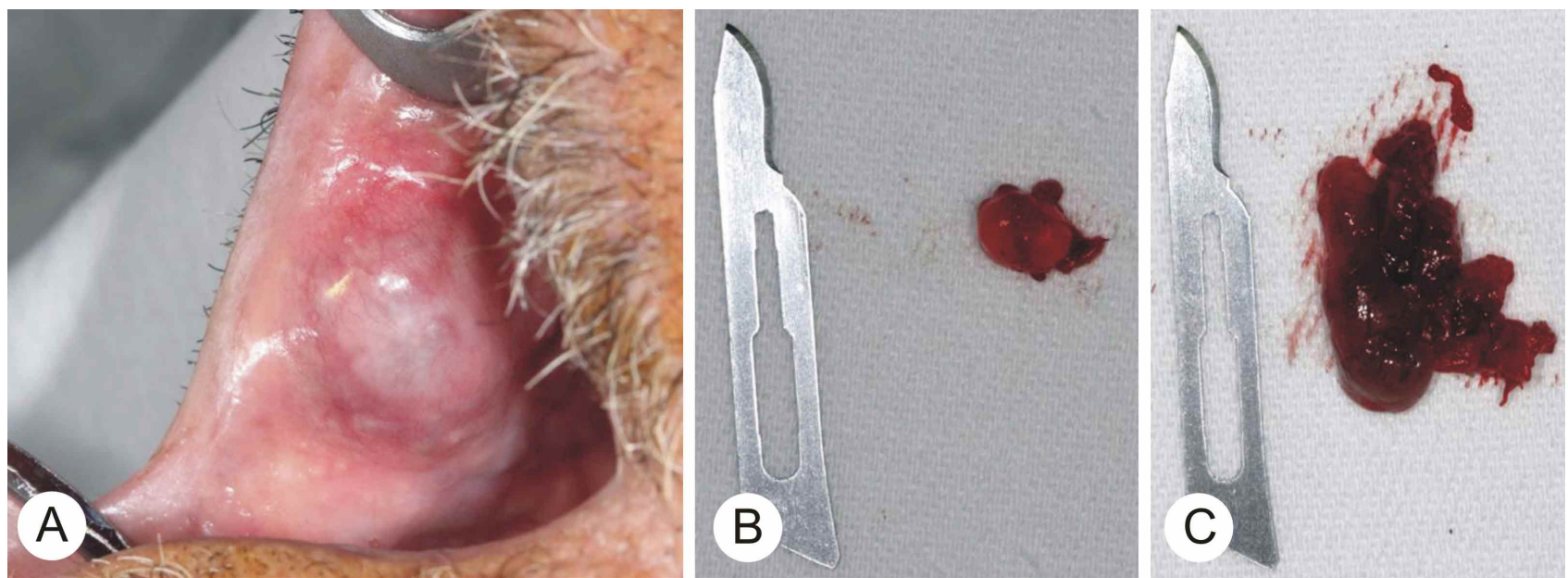

Fig. 1. A. Intraoral presentation of an apparent single sessile mass located at the right buccal mucosa. B-C, Macroscope aspect of the larger (B) and smaller lesions after surgical removal (C). 
A
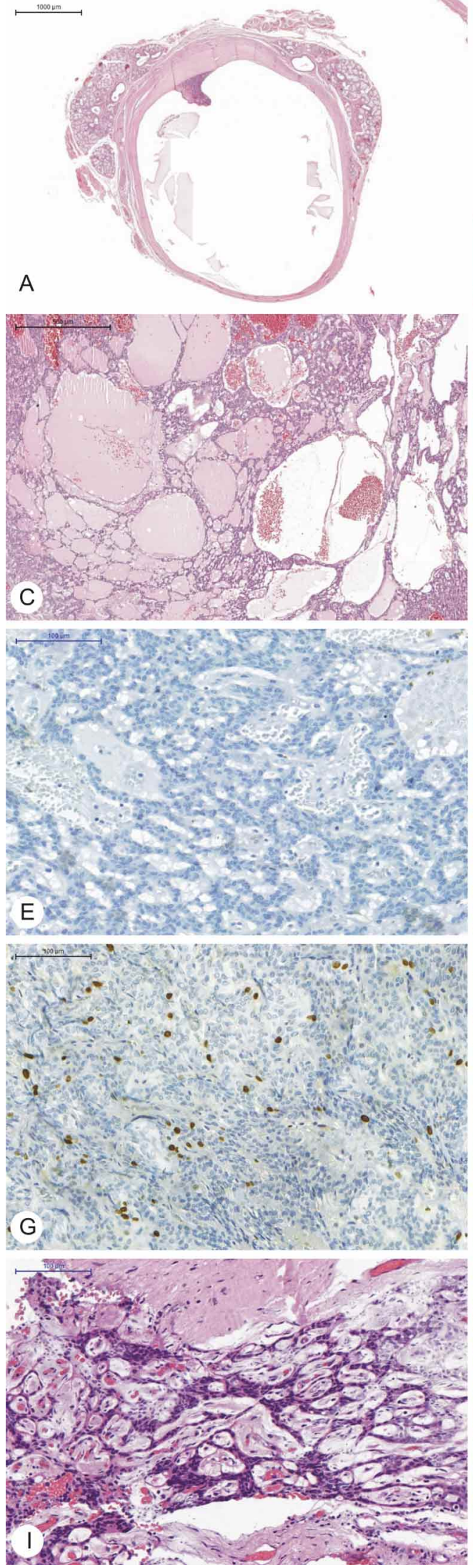
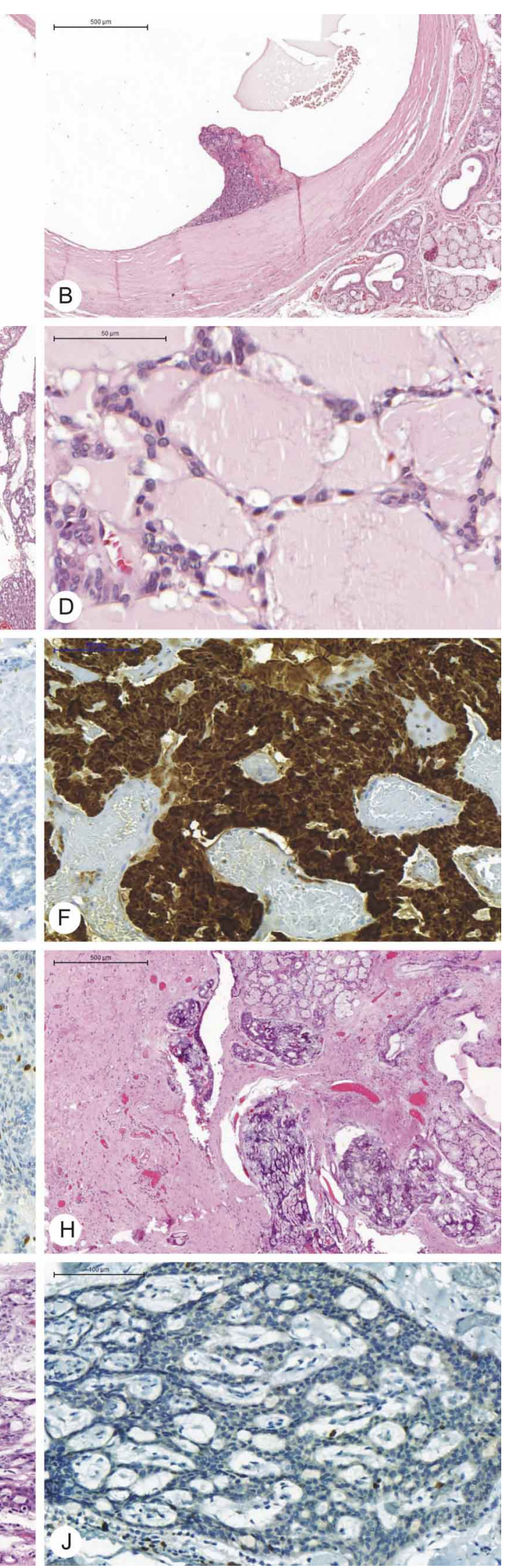

Fig. 2. Histopathological findings of the three biopsied lesions. A-B, Mucus extravasation phenomenon. The smaller lesion showed a pathological cavity (A) delimited by an intense granulation reaction and partially filled with mucin containing abundant foamy macrophages (B). C-G, Acinic cell carcinoma. C, The larger lesion was characterized by the proliferation of neoplastic cells arranged in a predominant thyroid-like follicular pattern. D, Multiple cystic spaces were filled with an eosinophilic protein material and delimited by polygonal cells with an eccentric nucleus. E, Negative staining for mammaglobin antibody. $F$, Strong labeling for S100 protein. G, Immunohistochemistry of Ki-67 antibody revealed a positive nuclear staining above $10 \%$. H-J, Adenoid cystic carcinoma. $\mathrm{H}$, The third lesion exhibited a proliferation of neoplastic cells arranged in a cribriform pattern with round pseudocystic structures. I, Lining these cyst-like spaces, it was observed a bilayer of basaloid cells with hyperchromatic nuclei and slight nuclear pleomorphism. J, Immunohistochemistry of Ki-67 protein revealed a weak staining for this marker. 
ANDRADE, A. L. D. L.; NETO, H. C.; DO CARMO, A. F.; SANTOS, E. M.; GERMANO, A. R. \& GALVÃO, H. C. Incidental discovery of acinic cell carcinoma of the oral mucosa with metachronous adenoid cystic carcinoma of the upper lip. Int. J. Odontostoma., 12(2):125-130, 2018.

mammary analogue secretory carcinoma (MASC). A negative staining for mammaglobin (Fig. 2E) and a strong labeling for S-100 protein (Fig. 2F) suggested the histopathological diagnosis of ACC. Immunohistochemistry using $\mathrm{Ki}-67$ antibody was performed to investigate the proliferative activity of the tumor and the results showed a nuclear staining above $10 \%$ (Fig. 2G).

The patient was referred to the Hospital of the Rio Grande do Norte League against Cancer for medical assessment and appeared at this center one year after the first consultation. Intraoral clinical examination showed a submucosal nodular lesion on the upper lip measuring approximately $0.5 \mathrm{~cm}$. An incisional biopsy was performed and histopathological analysis revealed the presence of a malignant neoplasm characterized by the proliferation of islands of neoplastic cells arranged in a cribriform pattern with round pseudocystic structures lined by a bilayer of basaloid cells (Fig. $2 \mathrm{H}$ ). Such tumor cells exhibited indistinct margins, cytoplasm varying from amphophilic to clear, hyperchromatic nuclei and slight nuclear pleomorphism (Fig. 2I). The surrounding stroma was formed by a fibrovascular connective tissue permeated by a mild lymphoplasmacytic inflammatory infiltrate. The histopathological diagnosis of this third lesion was AdCC. Immunohistochemical analysis of Ki67 protein revealed a weak staining for this marker (Fig. 2J).

To complement the surgical excision of the tumors, a few radiotherapy sessions were proposed, but the patient refused any additional treatment. However, three months after the second biopsy, the patient underwent surgical reconstruction of the treated areas and has been free of the disease for the past year.

\section{DISCUSSION}

Multiple salivary gland tumors (MSGTs) represent an unusual event characterized by the development of composite lesions originated from minor or major salivary glands (Seifert \& Donath, 1996). These neoplasms can be categorized into three perspectives: histologic type (identical or different histology), time of appearance (synchronous or metachronous) and topographic distribution (unilateral or bilateral) (Seifert \& Donath; Whitt et al.). Multiple malignant salivary gland tumors of the same histologic classification are more frequent than those of different histologic type, as well as a synchronous pattern of chronologic development has been observed in a large number of reported cases. In addition, major salivary glands are more usually affected than the minor salivary glands (Whitt et al.).

In this article, we report a case of a 73-year-old male patient that presented an ACC of the right oral mucosa combined with an AdCC of the right upper lip, which appeared one year later. In this perspective and according to the above criteria, the present case is an example of MSGTs with different histologic types, metachronous, unilateral and developed at minor salivary glands.

Considering the histopathologic features of MSGTs, three combinations have been found: composed benign tumors, benign and malignant lesions and exclusively malignant neoplasms (Argyris et al., 2014). Among these categories, multiple malignant salivary gland tumors are even more unusual and the present case represents an example of them (Whitt et al.).

Regarding the revised literature, a very few acceptable cases of multiple malignant minor salivary glands tumors were reported (Table I). Composed lesions of polymorphous low-grade adenocarcinoma are the most frequent histologic type. To our knowledge, the combination of ACC and AdCC in intraoral sites has not been reported in the literature.

As in the patient of the present case, the upper lips and oral are the most commonly affected intraoral locations and a peak incidence in the sixth and seventh decades of life is observed. Involvement of the minor salivary glands is uncommon and intraoral ACCs generally affect the oral mucosa, lips and palate (Triantafillidou et al.; Omlie \& Koutlas). Individual ACCs found in oral mucosa can often be confused with mucoceles, especially in cases involving the lower lip (Cho et al., 2005). In the present case, the clinical hypothesis of mucocele was raised because of its clinical appearance and the recurrent episodes of increasing and decreasing size of the lesion reported by the patient. After biopsy and histopathological examination, these clinical findings were explained by the presence of a mucocele adjacent to ACC.

With respect to sex, a male predilection was also identified in previous reports. Although both ACC and AdCC exhibited a female preference when appeared as single lesions (Seethala \& Barnes, 2011), our report is about a male patient. Unlike the present case, a predominance of synchronous lesions was verified in earlier articles. 
ANDRADE, A. L. D. L.; NETO, H. C.; DO CARMO, A. F.; SANTOS, E. M.; GERMANO, A. R. \& GALVÃO, H. C. Incidental discovery of acinic cell carcinoma of the oral mucosa with metachronous adenoid cystic carcinoma of the upper lip. Int. J. Odontostoma., 12(2):125-130, 2018.

Although hematoxylin-eosin staining remains as the golden standard method in definitive diagnosis of most salivary gland tumors, immunohistochemistry is an important complementary tool for pathologists to identify the cellular differentiation in difficult tumor cases (Cho et al.). Zymogen-poor ACC can be differentiated from MASC by immunohistochemical analysis using S-100 and mammaglobin antibodies. The majority of MASCs typically show strong staining for both markers, whereas ACCs commonly exhibit a negative or focally positive immunophenotype (Patel et al., 2013). However, S-100 protein has not proved specific or consistent enough to be reliably used in a diagnostic context (Cho et al.). Approximately $10 \%$ of the cases of ACC are immunoreactive for S-100 protein (Peel \& Seethala, 2007; Hellquist \& Skalova, 2014). On the other hand, AdCC specimens do not require immunohistochemical stains for diagnosis because the histological features are sufficient to prove it.

Because of the diversity of salivary gland tumors, each member of this group has its own unique histologic variants and specific prognostic pathologic features. Both ACCs and AdCCs are less common neoplasms and do not have a formalized grading system (Seethala \& Barnes). In this context, ACCs vary within a histomorphological spectrum that ranges from low to high grade. Low-grade ACCs are well-differentiated lesions that resemble the architecture of a normal salivary gland lobe. On the other hand, high-grade ACCs are poorly differentiated lesions that resemble the early stages of embryonic development of an acinus (Hoffman et al., 1999). Histopathological "grading" of AdCC is mostly based on the architectural growth pattern and determined according to the following categories: grade I, predominance of tubular pattern; grade II,-cribriform; and grade III, solid (Ellis \& Auclair; Seethala \& Barnes). According to the above criteria, the reported tumors were classified as low-grade ACC and AdCC with grade II.

In addition to histological grade, the prognosis of salivary tumors also depends on predictive biological factors such as type and location of the tumor, stage of the disease, duration of symptoms, and adequacy of surgical procedures (Nagao et al., 2002; Skálová et al., 2009). The investigation of biological markers is fundamental for predicting prognosis and for improving the understanding of the pathogenesis of salivary gland tumors. Among these biomarkers, analysis of the proliferative activity of salivary gland tumors using the MIB-1 or Ki-67 index is a highly efficient tool for the monitoring and prognosis of patients, and is considered an independent prognostic factor of patient survival (Velickovic et al., 2013). In our patient, immunohistochemical analysis of Ki-67 antibody revealed a more prominent staining in ACC specimen. Studies have shown that no recurrences were observed in ACCs with $\mathrm{Ki}-67$ index less than $5 \%$, and it was also reported that cases with an index above $10 \%$ were often associated with poor outcomes (Skálová \& Leivo, 1996; Velickovic' et al.). In the present case, Ki-67 index above $10 \%$ was observed in ACC specimen, a less favorable prognostic indicator (Velickovic et al.).

The treatment of salivary gland malignancies remains primarily surgical, but the use of adjuvant therapies, in particular radiotherapy, has resulted in improved locoregional control for patients with advancedstage disease (Bell et al.). Some factors have been documented by other studies to be associated with more aggressive disease and poor outcome, including: tumors with high-grade histology, locally or regionally advanced disease (T3, T4), positive margins, perineural/ angiolymphatic invasion, facial nerve involvement/facial paralysis and extraparotid/extracapsular extension (Hocwald et al., 2001; Jansisyanont et al., 2002; Bell et al.). Due to the appearance of a second primary tumor and to complement the surgical treatment, a few radiotherapy sessions were proposed to our patient, but he refused to do any additional treatment.

In summary, healthcare professionals should be aware of the presence of malignant salivary gland tumors, because of the potential for multiple lesions development. In this article, we report the first clinical case of combined $\mathrm{ACC}$ and AdCC arising in minor salivary gland tissue.

Table I. Previously reported cases of multiple malignant salivary gland neoplasms in intraoral locations, including the present case.

\begin{tabular}{lclcc}
\hline \multicolumn{1}{c}{ Author } & Age (yr) / Sex & Location & Histologic type & Temporality \\
\hline Appel et al. (1976) & 62 / F & Upper lip / upper lip & PLGA / PLGA & Synchronous \\
Clayton et al. (1995) & 68 / M & Oral mucosa / nasolabial fold & PLGA / PLGA & Synchronous \\
Clayton et al. (1995) & $70 / \mathrm{M}$ & Upper lip / buccal mucosa & PLGA / PLGA & Synchronous \\
Whitt et al. (2008) & $57 / \mathrm{M}$ & Palate / floor of mouth & MEC / AdCC & Metachronous \\
Present case & $73 / \mathrm{M}$ & Oral mucosa / upper lip & ACC / AdCC & Metachronous \\
\hline
\end{tabular}

ACC, acinic cell carcinoma; AdCC, adenoid cystic carcinoma; MEC, mucoepidermoid carcinoma; PLGA, polymorphous low-grade adenocarcinoma; yr, years. 
ANDRADE, A. L. D. L.; NETO, H. C.; DO CARMO, A. F.; SANTOS, E. M.; GERMANO, A. R. \& GALVÃO, H. C. Hallazgo incidental de carcinoma de células acinares de la mucosa oral con carcinoma adenoide quístico metacrónico del labio superior. Int. J. Odontostomat., 12(2):125-130, 2018.

RESUMEN: Los tumores de glándulas salivales múltiples representan un evento inusual caracterizado por el desarrollo de lesiones compuestas, originadas en glándulas salivales menores o mayores. Estos neoplasmas se pueden categorizar en tres perspectivas: tipo histológico, tiempo de aparición y distribución topográfica. Reportamos un caso inusual de un hombre negro de 73 años con un carcinoma de célula acínica (ACC) de la mucosa oral descubierta incidentalmente durante la extirpación quirúrgica de un mucocele adyacente. Aproximadamente un año después de la primera consulta, el paciente se presentó en el centro de referencia del cáncer local con una tercera lesión que fue diagnosticada como carcinoma adenoide quístico (AdCC) del labio superior. El paciente se sometió a la reconstrucción quirúrgica de las áreas tratadas y durante el último año no ha presentado recurrencia de la enfermedad. De acuerdo a nuestro conocimiento la combinación de ACC y AdCC en sitios intraorales no se ha informado en la literatura.

PALABRAS CLAVE: neoplasias de las glándulas salivales, carcinoma de células acínicas, carcinoma quístico adenoide, segundas neoplasias primarias metacrónicas.

\section{REFERENCES}

Appel, B. N.; El Attar, A. M.; Paladino, T. R. \& Verbin, R. S. Multifocal adenoid cystic carcinoma of the lip. Oral Surg. Oral Med. Oral Pathol., 41(6):764-71, 1976.

Argyris, P. P.; Gopalakrishnan, R.; Pambuccian, S. E.; Tosios, K. I. \& Koutlas, I. G. Polymorphous low-grade adenocarcinoma of the upper lip with metachronous myoepithelioma of the oral mucosa. Oral Surg. Oral Med. Oral Pathol. Oral Radiol., 117(6):e441-8, 2014.

Bell, R. B.; Dierks, E. J.; Homer, L. \& Potter, B. E. Management and outcome of patients with malignant salivary gland tumors. J. Oral Maxillofac. Surg., 63(7):917-28, 2005.

Cho, J. H.; Yoon, S. Y.; Bae, E. Y.; Lee, C. N.; Lee, J. D. \& Cho, S. H. Acinic cell carcinoma on the lower lip resembling a mucocele. Clin. Exp. Dermatol., 30(5):490-3, 2005.

Clayton, J. R.; Pogrel, M. A. \& Regezi, J. A. Simultaneous multifocal polymorphous low-grade adenocarcinoma. Report of two cases. Oral Surg. Oral Med. Oral Pathol. Oral Radiol. Endod., 80(1):71-7, 1995.

Du, F.; Zhou, C. X. \& Gao, Y. Myoepithelial differentiation in cribriform, tubular and solid pattern of adenoid cystic carcinoma: A potential involvement in histological grading and prognosis. Ann. Diagn. Pathol., 22:12-7, 2016.

Dubal, P. M.; Unsal, A. A.; Chung, S. Y.; Patel, A. V.; Park, R. C.; Baredes, S. \& Eloy, J. A. Population-based trends in outcomes in adenoid cystic carcinoma of the oral cavity. Am. J. Otolaryngol., 37(5):398-406, 2016.

Ellis, G. L. \& Auclair, P. L. Tumors of the Salivary Glands. In: AFIP Atlas of Tumor Pathology. Series 4. Washington D. C., American Registry of Pathology, 2008.

Hellquist, H. \& Skalova, A. Acinic Cell Carcinoma. In: Hellquist, H. \& Skalova, A. (Eds.). Histopathology of the Salivary Glands. Berlin, Springer, 2014. pp.261-78.
Hocwald, E.; Korkmaz, H.; Yoo, G. H.; Adsay, V.; Shibuya, T. Y.; Abrams, J. \& Jacobs, J. R. Prognostic factors in major salivary gland cancer. Laryngoscope, 111(8):1434-9, 2001.

Hoffman, H. T.; Karnell, L. H.; Robinson, R. A.; Pinkston, J. A. \& Menck, H. R. National Cancer Data Base report on cancer of the head and neck: acinic cell carcinoma. Head Neck, 21(4):297-309, 1999.

Jansisyanont, P.; Blanchaert, R. H. Jr. \& Ord, R. A. Intraoral minor salivary gland neoplasm: a single institution experience of 80 cases. Int. $J$. Oral Maxillofac. Surg., 31(3):257-61, 2002.

Luksic, I.; Baranovic, S.; Suton, P. \& Gerbl, D. Adenoid cystic carcinoma of the head and neck: a single-institution's analysis of 45 consecutive cases over a 29-year period. Oral Surg. Oral Med. Oral Pathol. Oral Radiol., 122(2):152-7, 2016.

Nagao, T.; Sugano, I.; Ishida, Y.; Asoh, A.; Munakata, S.; Yamazaki, K.; Konno, A.; Iwaya, K.; Shimizu, T.; Serizawa, H. \& Ebihara, Y. Hybrid carcinomas of the salivary glands: report of nine cases with a clinicopathologic, immunohistochemical, and p53 gene alteration analysis. Mod. Pathol., 15(7):724-33, 2002.

Omlie, J. E. \& Koutlas, I. G. Acinic cell carcinoma of minor salivary glands: a clinicopathologic study of 21 cases. J. Oral Maxillofac. Surg., 68(9):2053-7, 2010.

Patel, K. R.; Solomon, I. H.; El-Mofty, S. K.; Lewis, J. S. Jr. \& Chernock, R. D. Mammaglobin and S-100 immunoreactivity in salivary gland carcinomas other than mammary analogue secretory carcinoma. Hum. Pathol., 44(11):2501-8, 2013

Peel, R. L. \& Seethala, R. R. Pathology of Salivary Gland Disease. In: Myers, E. N. \& Ferris, R. L. (Eds.). Salivary Gland Disorders. Berlin, Springer, 2007. pp.33-104.

Seethala, R. R. \& Barnes, E. L. Common malignant salivary gland epithelial tumors. Surg. Pathol. Clin., 4(4):1177-215, 2011.

Seifert, G. \& Donath, K. Multiple tumours of the salivary glands--terminology and nomenclature. Eur. J. Cancer B Oral Oncol., 32B(1):3-7, 1996.

Shishegar, M.; Ashraf, M. J.; Azarpira, N.; Khademi, B.; Hashemi, B. \& Ashrafi, A. Salivary gland tumors in maxillofacial region: a retrospective study of 130 cases in a southern Iranian population. Patholog. Res. Int., 2011:934350, 2011.

Skálová, A. \& Leivo, I. Cell proliferation in salivary gland tumors. Gen. Diagn. Pathol., 142(1):7-16, 1996.

Skálová, A.; Sima, R.; Vanecek, T.; Muller, S.; Korabecna, M.; Nemcova, J.; Elmberger, G.; Leivo, I.; Passador-Santos, F.; Walter, J.;Rousarova, M.; Jedlickova, K.; Curik, R.; Geierova, M. \& Michal, M. Acinic cell carcinoma with high-grade transformation: a report of 9 cases with immunohistochemical study and analysis of TP53 and HER-2/neu genes. Am. J. Surg. Pathol., 33(8):1137-45, 2009.

Triantafillidou, K.; Iordanidis, F.; Psomaderis, K. \& Kalimeras, E. Acinic cell carcinoma of minor salivary glands: a clinical and immunohistochemical study. J. Oral Maxillofac. Surg., 68(10):248996, 2010.

Velickovic, L. J.; Dimov, I.; Petrovic, D.; Stojnev, S.; Dacic, S.; Velickovic, S. \& Stefanovic, V. Stromal reaction and prognosis in acinic cell carcinoma of the salivary gland. Vojnosanit. Pregl., 70(12):1155-8, 2013.

Whitt, J. C.; Schafer, D. R. \& Callihan, M. D. Multiple malignant salivary gland neoplasms: mucoepidermoid carcinoma of palate and adenoid cystic carcinoma of floor of mouth. Head Neck Pathol., 2(1):41-8, 2008.

Corresponding author:

Ana Luiza Dias Leite de Andrade

Universidade Federal do Rio Grande do Norte

Departamento de Odontologia

Av. Senador Salgado Filho, 1787

Lagoa Nova - Natal

RN -BRAZIL

Received: 05-02-2018

Accepted: 13-04-2018

E-mail: ana_luiza_dla@hotmail.com 